\title{
COLLABORATIVE PARTNERSHIP PARADIGM IN THE SUSTAINABILITY-ORIENTED SUPPLY CHAIN AS THE WAY TO SUSTAINABILITY
}

\author{
RAKIC, B.* - RAKIC, M. \\ Faculty of Business Studies \\ Marsala Tolbuhina 8, 11070 Belgrade, Serbia \\ (phone: +381-11-220-3011; fax: +381-11-220-3011) \\ *Corresponding author \\ e-mail:brakic@gmail.com(brakic@megatrend.edu.rs) \\ (Received $23^{\text {rd }}$ Jan 2018; accepted $25^{\text {th }}$ Apr 2018)
}

\begin{abstract}
This study extends research into power in the supply chain (SC) on the basis of three "patterns". The first one is the "pattern of sustainability". From the aspect of sustainability, the "golden thread" connecting all actors and influencing relationships between actors in the SC is the sustainability orientation. The second one is the "pattern of sustainability-oriented (SO) actors". Transformation towards sustainability in the SC requires the SO behavior of numerous actors. The third one is the "pattern of SO collaboration". Sustainability results from the complementary effect of numerous actors' behaviors, so this study suggests the SO collaboration paradigm as a way to sustainability. These three patterns of embedding sustainability in the SC can also be observed as the three stages of the transformation of the SC into the sustainability-oriented supply chain (SO-SC). In the first stage of embedding sustainability in the SC, actors voluntarily and/or under pressures accept some sustainability initiatives. In the second stage, the number of SO actors behaving sustainably increases. The SO-SC and the achievement of the goals of the sustainable development (SD) require the sustainable behavior of all (or at least) the majority of actors and SO collaboration.
\end{abstract}

Keywords: sustainable development, Agenda for sustainable development, environmental awareness, cocreation of value, consumer

\section{Introduction}

Individuals, companies and countries are faced with an SD challenge. According to "The 2030 Agenda for Sustainable Development" (UN, 2015), all countries and all stakeholders are actors taking part in a collaborative partnership, in which Governments, civil society, the private sector, the United Nations' system and other actors are brought together and all available resources are mobilized. Lozano et al. (2015) proposed the 'Sustainability-Oriented Theory of the Firm', which is based on the holistic perspective of corporate sustainability. SO actors enable transformations in the SC. In compliance with the Agenda for SD (UN, 2015), all actors and all stakeholders are actors taking part in a collaborative partnership in the SC, where consumers, the focal firm, employees, suppliers, regulators and governments, the general public, environmental and social pressure groups, NGOs, neighborhood communities, the media and schools are brought together. Starting from the literature review, the purpose of the study is to present and analyze the collaborative partnership paradigm in the SOSC as a way to sustainability. "Sustainability-oriented" (SO) means a holistic approach to sustainability by covering all the three dimensions (economic, environmental and social) in the dynamic process (Rakic and Rakic, 2017b). According to the collaborative partnership paradigm in the SO-SC, all actors are engaged in co-creating $\mathrm{SO}$ values. Consumers are the most important co-creators of values. Opportunities for firms are the 
speed (of business and change), digitalization and the SO-SC. These are also the sources of companies' competitive advantages.

The structure of the study is as follows. In the next section, the related literature is reviewed. Then, the conceptual framework - the collaborative partnership paradigm is presented and described, as a way to sustainability in the SC. The conclusions and the agenda for further research are presented at the end of the paper.

\section{The engagement of co-creators in sustainable supply-chain management}

In firms, there are stakeholders with different priorities because of the protuberance of their values and issues, for which reason the same are often compelled to make tradeoffs. For example, owners' and managers' focus is on profitability, whereas concerns of a community's members are probably related to the overall livability of the community and production's environmental impacts. How to balance environmental issues and sound business practices in such a dynamic, complex and uncertain setting is challenging. One research, however, suggests that it is impossible for all stakeholders to be satisfied at all points in time. Ambitiously environmentally targeted strategic decisions can generate real economic costs (Pagell et al., 2010). Firms have increasingly been facing pressure from external stakeholders (e.g. NGOs, customers, regulators) in order for them to maintain sustainable supply chains (Grimm et al., 2014). Searcy (2014) differentiates three groups of stakeholders for the sustainability of an enterprise:

- focal firm stakeholders - employees, unions, managers, owners/investors

- supply chain stakeholders - suppliers, distributors, consumers (individuals, groups or other firms), reclaimers (collectors, re-users, recyclers, remanufacturers or disposers)

- stakeholders beyond the supply chain - government, communities, competitors, NGOs, media.

\section{The engagement of co-creators in the sustainability-oriented internal value chain}

Focal firms are those usually (1) ruling or governing the supply chain, (2) providing the customer with a direct contact, and (3) designing the product or service offered (Seuring and Muller, 2008). The focal firm is capable of arranging for the maximum benefit for all the participants of the supply chain through their coordination, the inhibition of an opportunistic behavior, and the maintenance of the sustainability of the supply chain (Li et al., 2014).

\section{The influences of external stakeholders}

It is possible to group external drivers at three levels, and by rule they include:

- Regulators and governments at the regulatory level

- Customers, suppliers and competitors at the market level

- Non-governmental organizations (NGOs) and the general public at the societal level (Harms et al., 2013).

From the historical point of view, firms used to accumulate all the resources they were in need of in-house. Today, firms have shifted away from this vertical-integration model and have started programs intended for accessing specialized, global suppliers (Prahalad and Krishnan, 2008). Production processes are frequently dispersed throughout the globe. Supply-chain focal firms might be held responsible for their 
suppliers' environmental and social performance (Seuring and Muller, 2008). Focal firms, buyers, are required to take their suppliers' responsibility, sustainably arranging for their supply chains' actions. It is frequently the case that external stakeholders do not differentiate the focal firm's behavior from the one of its suppliers, simultaneously holding the focal firm responsible for all activities performed within the manufacture of a product (Grimm et al., 2014; Rao, 2002; Koplin et al., 2007). Any party in the supply chain that does not comply with the focal firm's corporate sustainability standards can potentially incur damage to corporate reputation and/or harm customer confidence (Grimm et al., 2014) (Seuring and Muller, 2008). This is particularly the case with brand-owning firms, since they show a tendency of being exposed to pressure from stakeholders, e.g. non-governmental organizations (NGOs). Mattel (Barbie), Nike (Football) and Nestlé (KitKat) are outstanding examples to have demonstrated the way in which firms' brands can suffer from non-compliant sub-suppliers (Barnett and King, 2008; Choi and Linton, 2011; Grimm et al., 2014; Wagner et al., 2009). On the other hand, when the focal firm is exposed to pressure, it usually passes such pressure on to suppliers (Seuring and Muller, 2008). The idea is that the focal firm in the supply chain will compel its upstream suppliers to adopt and adapt the technology and practices resulting in more efficient and environmentally friendly material sources, engage in labor practices deemed to be ethical and result in the lower emissions of the greenhouse gas and a low impact on the environment. As it has been suggested that "a firm is only as sustainable as it suppliers".

Gualandris and Kalchschmidt (2014) recommend that the growing awareness on the stakeholders' part should be acknowledged by managers and that they should be prepared to address strict environmental and social requirements made by the customer. Customer pressure is found to be the essential driver motivating firms to initiate and sustain the process of the SSCM development. Customer pressure refers to endconsumers' and business customers' requests and their requirements, i.e. those made by important primary-stakeholder groups, so that the firm could make its environmental and social performance upgraded (Gualandris and Kalchschmidt, 2014). One of the key criteria for decision making that has so far been missing from green, SSC models is the consumer's role. Many businesses selling environmentally friendly, green or sustainable, low-carbon-emission products show a tendency of costing more. The consumer is usually passed on this cost in the form of higher prices. For the purpose of making green or sustainable products more marketable and sellable, many businesses will not only have to quantify the benefits, but also to justify the value proposition to the customer (Hassini et al., 2012). The factors related to marketing and public relations refer to firms' efforts intended for the creation of a value proposition for the customer, in particular when an "environmentally friendly" product costs more. Also, firms must create the awareness of the practices leading to a more environmentally friendly or sustainable product. Just like focal firms in the supply chain compel their upstream suppliers to be greener and more sustainable, they also try to educate and convince their customers to purchase their green products. As an external pressure, NGO's can turn to boycotts or detrimental publicity campaigns designed to shame the firm into offering more sustainable products (Hassini et al., 2012).

Customer expectations have become the most important external pressure (Doonan et al., 2005). The increasing of his/her environmental, ecological and ethical awareness by the end-customer and demands to save energy, reduce pollution and waste, as well as ensure consumer safety, expose supply management to pressure (Lintukangas et al., 2015). 
The factors related to the policy and regulations originate from governments either through legislation or via a regulator requesting from firms to obey certain environmental standards (Hassini et al., 2012). "If conservationists, environmentalists and animal advocates join forces, perhaps there will be some reason for optimism" (Erdos et al., 2017, p. 188).

\section{From dyadic, via triadic to multiple relationships in supply chain}

From a traditional point of view, power relationships are surveyed at the dyadic level (Touboulic et al., 2014), namely most frequently between the local firm (the buyer) and its suppliers (Brammer et al., 2011; Kumar and Rahman, 2015). One side of the relationship dyad has been the subject matter of such studies (Nyaga et al., 2013). Mainly, one actor's responsibilities, namely those on the part of the focal firm (the buying firm) are singled out. Relationships existing between the focal firm other actors, e.g. retailers, are researched into to a lesser extent (Chaurasia, 2014). The end consumer is rarely the focal subject matter of research. When buyers are mentioned and an analysis of them performed, authors actually analyze relationships between the focal firm and suppliers (in which case, the focal firm is considered as the buyer, i.e. the firm as the buyer). This study emphasizes the role of the end consumer.

Apart from dyadic relationships, authors have also done research into triadic relationships (Touboulic et al., 2014), as well as into network relationships (Lacoste and Johnsen, 2015; Tachizawa and Wong, 2015). Touboulic et al. (2014) observe multiple triadic relationships drawing in a large buyer and its small suppliers, in order to check thoroughly into the manner in which relative power may affect the implementation of sustainable supply-management practices. They are analyzed at the triad level of analysis: the buyer-the supplier-the supplier. According to the results of the research, it is possible for a powerful organization to drive sustainability in its SC. When a situation such as the described one occurs, dependent suppliers are not left too much choice they can but adhere to requirements made by the buyer and it is their obligation to specifically perform a thorough check into the relationship in order to become more sustainable. The findings are conforming to the work previously conducted, in which a suggestion was made that the buyer power stands for a resource to be used for the purpose of compelling the supplier to be compliant with sustainability requirements (Touboulic et al., 2014).

Tachizawa and Wong (2015) propose that a supply network perspective should be used to carry out an analysis of the effectiveness of the mechanisms of governance of green supply chain management (GSCM), not to apply a linear view. There are increasing societal pressures that encircle firms' accountability for the environment, which is accompanied, too, by an ever-larger number of environmental scandals concerning supply networks. It may prove to be insufficient to only apply the traditional frameworks of the governance of the GSCM for the purpose of dealing with this new reality, because the supply network structure/complexity is not taken into consideration, nor is the manner in which these factors interact with different mechanisms of governance is considered, either (Tachizawa and Wong, 2015). It is possible to understand that the supply network is a set of firms taking part, directly or indirectly, in supplying industrial inputs to the focal firm, with or without that company being aware or knowledgeable of it (Choi and Krause, 2006; Choi et al., 2001). Supply networks are viewed by Tachizawa and Wong (2015) as emergent, allowing for different parties 
capable of shaping the supply network and the implementation of the GSCM. For a long time, the importance of power and dependence in relationships has been the subject matter of consideration by IMP. In the IMP literature, power distribution is considered as being dependent on the pattern of the 'interaction' (Hakansson and Waluszewski, 2013; Lacoste and Johnsen, 2015). The IMP paradigm of the interaction approach takes place within the context of relationships between companies embedded in networks (Campbell, 1984; Hakansson, 1986; Lacoste and Johnsen, 2015; Smith and Easton, 1986). Zhao et al. (2008) pointed out the impact of relationship commitment on the integration between actors in the SC. Relationship commitment is one party's willingness to make an investment of its own financial, physical or relationship-based resources in a relationship (Morgan and Hunt, 1994). Quite a large amount of time and resources are invested by firms in the development, maintenance and improvement of the relationships between them in the supply chain since demonstrable benefits in terms of operational and financial performance are offered by such relationships (Nyaga et al., 2013). Firms cooperate with their respective partners in the supply chain so that they could have access to critical resources, mitigate transactional complexity and improve their performance (Fawcett et al., 2011; Nyaga et al., 2013; Zacharia, 2009). It is possible to foster sustainability by making a connection between the concept of cocreation and the concept of relationship management. Co-creation implies an inclusion of well-selected stakeholders, e.g. customers or suppliers, in the innovation process on a targeted basis (Arnold, 2017).

Traditionally in the SC literature, the concept of power in buyer-supplier exchange has been a significant subject matter of researches conducted. When a shift from supply chain management (SCM) to sustainable supply chain management (SSCM) is considered, it is possible for relationship-management strategies to undergo significant changes so as to be able to accommodate sustainability goals with e.g. dominant buyers who do not exploit their power over dependent suppliers but instead treat them as if they were strategic partners (Pagell et al., 2010; Touboulic et al., 2014). In prior researches, a strong accent has been put on cooperation between SC partners for the purpose of facilitating sustainability initiatives (e.g., Gold et al., 2010; Grekova et al., 2016; Lacoste and Johnsen, 2015; Sancha et al., 2016; Seuring and Muller, 2008; Touboulic et al., 2014). While, on the one hand, cooperation has been publically supported as the best manner to manage SC relationships regarding sustainability, that the fact that the major part of the SSCM literature tends to focus on actions performed by large corporations, on the other, is an interesting one to perceive. Cooperation with suppliers has been regarded as a critical component of creating sustainable SCs (Touboulic et al., 2014). Little research has been done that may challenge the collaborative paradigm in SSCM, and power relationships stay underexplored (Hoejmose and Adrien-Kirby, 2012; Walker et al., 2012). A larger number of the case studies appearing in the SSCM literature are a demonstration of some sort of power imbalance, which will not only determine the agenda driver, but also have an impact on the implementation and outcomes of sustainability initiatives (Touboulic et al., 2014).

\section{Conceptual framework - the collaborative partnership paradigm in the sustainability-oriented supply chain as the way to sustainability}

This study is focused on the SO collaboration paradigm (Fig. 1). According to the SO collaboration paradigm, all actors and all stakeholders act in a collaborative 
partnership, bringing together consumers, focal firm, employees, suppliers, regulators and governments, the general public, environmental and social pressure groups, NGOs, neighborhood communities, media, schools and universities. The full line shows the relations between actors from the aspect of the focal firm. The interrupted (dotted) line shows the relations of other actors which the focal company does not directly participate in.

\section{SO actors in macro environment}

Regulators and governments, the general public, environmental and social pressure groups, NGOs, neighborhood communities, the media and schools

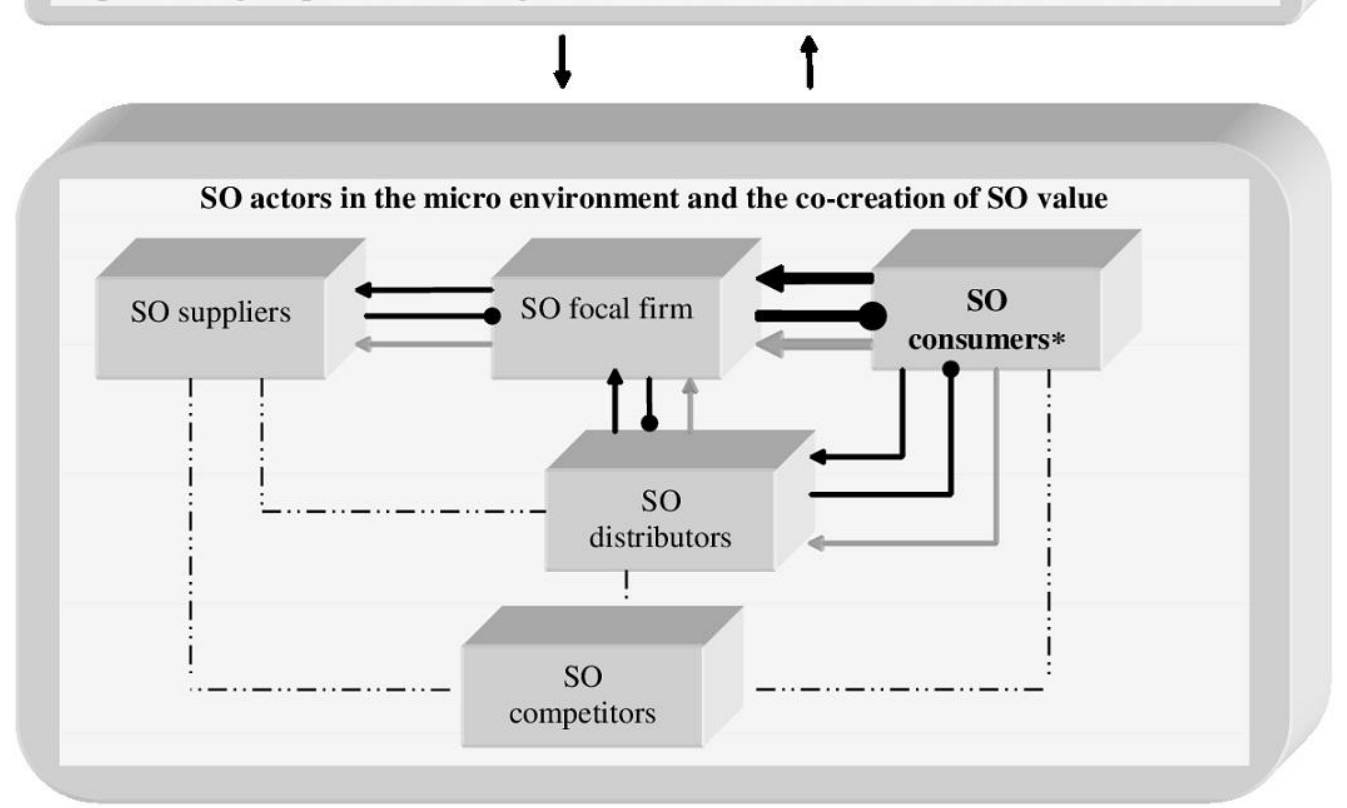

* End consumers: offline, online; individuals, consumer communities

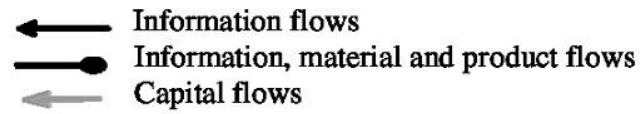

Figure 1. Conceptual Framework - the Collaborative Partnership Paradigm in the Sustainability-Oriented Supply Chain as the Way to Sustainability (Source: Authors)

Each of the foregoing actors has its own "patterns of sustainable behavior" and has an influence on other actors and the SC as a whole. SO actors co-create SO value (Rakic and Rakic, 2015a,b, 2017a,b). The focal firm (the brand name) appears in the market in public and is frequently considered to be the main responsible actor. The SO-SC, however, depends on numerous actors' sustainable behavior. The key actors are consumers, focal firms, suppliers, competitors and distributors.

The thickness of the line in Figure 1 between consumers and the focal firm places an accent on the fact that consumers are in focus and that end consumers' needs and wants are (or at least should be) the starting point. Consumer behavior (of end consumers) has an influence on the buying behavior of organizations (B2B). The SO lifestyle of end consumers is "the foundation of sustainability". In the traditional and digital worlds, 
consumers appear as individuals and within consumer communities. The power that consumers have in the digital world is even greater. Consumers in the digital era are in a position to be the most important co-creators of value; yet, they are not aware of their power. The speed of content distribution on the Internet (via social media - especially through social networks and blogs, portals, etc.), the consumers' awareness of a healthy lifestyle and the tendency to preserve the environment will affect the sustainable behavior of an increasing number of consumers. This will further affect the sustainable behavior of all other stakeholders in the supply chain. Consumers can create, comment and share content through social media. Consumers can influence the business and image of firms. On the other hand, the firms based on word-of-mouth marketing can influence the word-of-mouth communication of consumers. Content, like a virus, can be transmitted over the Internet. Responsible actors can use the power of viral marketing to create content about the importance of sustainable behavior for all actors. Companies can encourage influential people (bloggers and various activists in the field of sustainable development) to create, comment and share the content about sustainable behavior.

If end consumers behave sustainably, then firms as buyers also have to behave sustainably. SO consumers have an influence on the "sustainability mindset" and behavior on the B2B market. Then, the focal firm (as the buyer) has to conduct sustainable production, purchase sustainable inputs from SO suppliers and submit sustainable inputs to SO consumers directly and/or through SO distributors. The SO-SC is an opportunity, not a threat, for firms. The speed (of business and change), digitalization and the SO-SC are opportunities for firms.

$\mathrm{SO}$ actors in the macro-environment (regulators and governments, the general public, environmental and social pressure groups, NGOs, neighborhood communities, the media and schools) have the roles of setting "the patterns of sustainable behavior", promotions, pressures and controls of actors' sustainable behavior.

This conceptual framework presents:

- SO actors in a macro-environment;

- SO actors in a micro-environment;

- the mutual relations of the macro-environment and the micro-environment;

- the mutual relations of actors in the micro-environment;

- the collaborative partnership of actors in the process of the co-creating of SO value;

- actors in the SC as the co-creators of SO value;

- information, the material, the product and capital flows in the microenvironment;

- end consumers as offline and online consumers; individuals and consumer communities;

- the dominant role of SO consumers in the process of the co-creation of SO value in the $\mathrm{SC}$;

- the power of SO consumers as the co-creators of SO value -the impact of consumer behavior and the consumers' SO lifestyle on the SO behavior of all actors in SC-SO consumers as the initiators of the co-creating of $\mathrm{SO}$ value;

- the SO-SC as a result of the complementary action of numerous actors' sustainable behavior; and

- the SO behavior of all actors in the SC for the purpose of achieving SD goals. 
The New Agenda for Sustainable Development emphasizes the need for "transforming our world". Embedding sustainability into the SC is part of the holistic perspective of sustainability. Actors have become involved in embedding the principles of sustainable development in the SC. Adaptations in the SC are based on three patterns. The first one is "the sustainability pattern", i.e. the acceptance and adherence to sustainability initiatives. The second one is the "pattern of SO actors". In order to achieve sustainability in the SC, it is needed that numerous SO actors should be engaged, including consumers, the focal firm, employees, suppliers, regulators and governments, the general public, environmental and social pressure groups, NGOs, neighborhood communities, the media, schools and universities. Many actors' "SO mindsets" have an influence on the achievement of the SD goals. For that reason, SO collaboration and the application of the "pattern of SO collaboration" are needed. These are simultaneously the three stages in embedding sustainability in the SC and the three stages on the pathway from SO actors in the SC to the SSC. In phase one, the introduction of sustainability in the SC is understood and accepted. In the second phase of embedding sustainability in the SC, for a more significant acceptance of sustainability in the SC as many SO actors as possible need to be engaged towards achieving sustainable behavior, amongst them - end consumers in particular. Ultimately, in the third phase, in order to achieve SD goals, the majority of actors need to be SO and behave in a sustainable manner, so that the "pattern of SO collaboration" is in focus.

\section{Conclusion}

According to the SO collaboration paradigm, all actors and all stakeholders act in a collaborative partnership for the purpose of achieving SD goals. The SO-SC is a result of a complementary action of numerous actors' sustainable behavior. Embedding sustainability in the lifestyle of end consumers is the basis of end-consumer sustainability. Embedding sustainability in the SC of firms as buyers (B2B) is one part of the holistic perspective of corporate sustainability. Embedding sustainability in actors' behavior is one part of the holistic perspective of the SD. SO actors in the SC influence the sustainability of individuals, companies and countries. Actors' sustainable behavior and collaborative partnership lead "to achieving SD in its three dimensions economic, social and environmental - in a balanced and integrated manner" (UN, 215, p. 3).

The contributions of this paper are as follows:

- placing an emphasis on the co-creating of SO value in the SC,

- the presentation of the co-creators of SO value in the SC,

- the presentation of the SO behavior of all actors in the SC for the purpose of achieving SD goals,

- the SO-SC as a result of the complementary action of the sustainable behavior of numerous actors,

- placing an emphasis on the power of SO consumers as the co-creators of SO value - the impact of consumer behavior and the consumers' SO lifestyle on the SO behavior of all actors in the SC,

- the presentation of the three patterns of embedding sustainability in the SC, 
- the presentation of the three stages of the transformation of the SC into the SO$\mathrm{SC}$,

- the presentation and analysis of the conceptual framework: the collaborative partnership paradigm in the SO-SC as a way to sustainability.

Our proposed framework (Fig. 1) require empirical validation. Those could be the bases for future research. The research questions could be:

- Are stakeholders in the supply chain aware of the fact that they are the coauthors of values?

- Can stakeholders from the macro-environment influence the SO behaviour of consumers and other actors in the micro-environment?

- Can the focal firm influence the behaviour of other actors in the supply chain?

- Are consumer behaviour and the consumer lifestyle the basis of sustainability?

- Does SO consumer behaviour influence the SO behaviour of other actors in the supply chain?

- Are consumers aware of their having the power and of the fact that, by purchasing products/services, they can affect the survival of companies? Are consumers aware of the fact that their responsible behaviour can affect the responsible behaviour of companies and of all other stakeholders?

- Can sustainability marketing influence the behaviour of actors?

- Is viral marketing an opportunity or threat for actors in the supply chain in today's digital world?

- What and how can the co-creators of value in the supply chain do for sustainable development and sustainability?

The conclusion is that consumers are the most important co-creators of values. The trends in the field, such as digitalization and the orientation towards sustainable development, will affect consumers in such a manner as to make them understand the power they have as the initiators of the co-creation of SO value. Other stakeholders, especially firms, should realize that the sources of a competitive advantage today are: the speed, digitalization and the co-creation of SO value. The conceptual framework the collaborative partnership paradigm in the SO-SC could be a way to sustainability.

\section{REFERENCES}

[1] Arnold, M. (2017): Fostering sustainability by linking co-creation and relationship management concepts. - Journal of Cleaner Production 140(1): 179-188.

[2] Barnett, M.L., King, A.A. (2008): Good fences make good neighbors: a longitudinal analysis of an industry self-regulatory institution. - Academy of Management Journal 51(6): 1150-1170.

[3] Brammer, S., Hoejmose, S., Millington, A. (2011): Managing sustainable global supply chains: A systematic review of the body of knowledge. Report. Network for Business Sustainability, Retrieved from http://nbs.net/wp-content/uploads/nbs-systematic-reviewsupply-chains.pdf

[4] Campbell, N.C.G. (1984): The structure and stability of industrial market networks: developing a research methodology. In: First IMP Conference on Research Developments in International Marketing, Manchester: UMIST.

[5] Chaurasia, S. (2014): An Empirical Analysis of Power in Retailer-Manufacturer Supply Chain Relationship: A Resource Dependency Perspective. - The IUP Journal of Supply Chain Management 11(1): 52-66. 
[6] Choi, T. Y., Doolety, K., Rungtusanatham, M. (2001): Supply networks and complex adaptive systems: Control versus emergence. - Journal of Operations Management 19 (3): 351-366.

[7] Choi, T. Y., Krause, D. R. (2006): The supply base and its complexity: Implications for transaction costs, risks, responsiveness, and innovation. - Journal of Operations Management 24 (5): 637-652.

[8] Choi, T.Y., Linton, T. (2011): Don't let your supply chain control your business. Harvard Business Review (December): 112-117.

[9] Doonan, J.; Lanoie, P.; Laplante, B., (2005): Analysis determinants of environmental performance in the canadian pulp and paper industry: an assessment from inside the industry. - Ecological Economics 55: 73-84.

[10] Erdos, L., Tolgyesi, CS., Batori, Z., Magnes, M., Tolnay, D., Bruers, S. (2017): Three sides of the same coin? The main directions of the environmental movement. - Applied Ecology and Environmental Research 15(4):177-194.

[11] Fawcett, S. E., Wallin, C., Allred, C., Fawcett, A. M., Magnan, G. M. (2011): Information technology as an enabler of supply chain collaboration: A dynamiccapabilities perspective. - Journal of Supply Chain Management 47(1): 38-59.

[12] Gold, S., Seuring, S., Beske, P. (2010): Sustainable supply chain management and interorganizational resources: A literature review. - Corporate Social Responsibility and Environmental Management 17(4): 230-245.

[13] Grekova, K., Calantone, R.J., Bremmers, H.J., Trienekens, J.H., Omta, S.W.F. (2016): How environmental collaboration with suppliers and customers influences firm performance: evidence from Dutch food and beverage-processors. - Journal of Cleaner Production 112(3): 1861-1871.

[14] Grimm, J.H., Hofstetter, J.S., Sarkis, J. (2014): Critical factors for sub-supplier management: A sustainable food supply chains perspective. - International Journal of Production Economics 152(C): 159-173.

[15] Gualandris, J., Kalchschmidt, M. (2014): Customer pressure and innovativeness: Their role in sustainable supply chain management. - Journal of Purchasing and Supply Management 20: 92-103.

[16] Hakansson, H. (1986): Relationships marketing strategies and competitive strength. In: Turnbull, P.W., Valla, J.P. (Eds.), Strategies for International Industrial Marketing. London: Croom Helm.

[17] Hakansson, H., Waluszewski, A. (2013): A never ending story - interaction patterns and economic development. - Industrial Marketing Management 42(3): 443-454.

[18] Harms, D., Hansen, E.G., Schaltegger, S. (2013): Strategies in Sustainable Supply Chain Management: An Empirical Investigation of Large German Companies. - Corporate Social Responsibility and Environmental Management 20: 205-218.

[19] Hassini, E., Surti, C., Searcy, C. (2012): A literature review and a case study of sustainable supply chains with a focus on metrics. - International Journal of Production Economics 140: 69-82.

[20] Hoejmose, S. U., Adrien-Kirby, A. J. (2012): Socially and environmentally responsible procurement: A literature review and future research agenda of a managerial issue in the 21st century. - Journal of Purchasing \& Supply Management 18(4): 232-242.

[21] Koplin, J., Seuring, S., Mesterharm, M. (2007): Incorporating sustainability into supply management in the automotive industry - The case of theVolkswagen. AG.J. - Journal of Cleaner Production 15(11-12): 1053-1062.

[22] Kumar, D., Rahman, Z. (2015): Sustainability adoption through buyer supplier relationship across supply chain: A literature review and conceptual framework. International Strategic Management Review 3(1-2): 110-127.

[23] Lacoste, S., Johnsen, R. (2015): Supplier-customer relationships: A case study of power dynamics. - Journal of Purchasing \& Supply Management 21(4): 229-240. 
[24] Li, Y., Zhao, X., Shi, D., Li, X. (2014): Governance of sustainable supply chains in the fast fashion industry. - European Management Journal 32: 823-836.

[25] Lintukangas, K., Hallikas, J., Kähkönen, A-K. (2015): The Role of Green Supply Management in the Development of Sustainable Supply Chain. - Corporate Social Responsibility and Environmental Management 22(6): 321-333.

[26] Lozano, R., Carpenter, A., Huisingh, D. (2015): A review of 'theories of the firm' and their contributions to Corporate Sustainability. - Journal of Cleaner Production 106(1): 430-442.

[27] Morgan, R.M., Hunt, S.D. (1994): The commitment-trust theory of relationship marketing. - Journal of Marketing 58(3): 20-38.

[28] Nyaga, G.N., Lynch, D.F., Marshall, D., Ambrose, E. (2013): Power Asymmetry, Adaptation and Collaboration in Dyadic Relationships Involving a Powerful Partner. - Journal of Supply Chain Management 49(3): 42-65.

[29] Pagell, M., Wu, Z., Wasserman, M. E. (2010): Thinking differently about purchasing portfolios: An assessment of sustainable sourcing. - Journal of Supply Chain Management 46(1): 57-73.

[30] Prahalad, C., Krishnan, M.S. (2008): The new age of innovation - driving co-created value through global networks, McGraw Hill, USA.

[31] Rakic, B., Rakic, M. (2015a): Holistic management of sustainability marketing in the process of sustainable development. - Environmental Engineering and Management Journal 14(4): 887-900.

[32] Rakic, M., Rakic, B. (2015b): Sustainable Lifestyle Marketing of Individuals: the Base of Sustainability, - Amfiteatru Economic 17(40): 891-908.

[33] Rakic, B., Rakic, M. (2017a): From Marketing Myopia to Contemporary Marketing: Transformations in Marketing in the Context of Digitalization and Sustainability (Integration of Traditional, Digital, Co-Creative and SustainabilityOriented Mindsets Inside Actors in Contemporary Marketing). Digital Book, available at eBook retailers: Amazon.com - Kindle Store, etc.; Kindle Edition, ASIN: B06WGV26DT, Retrieved from https://www.amazon.com/Marketing-MyopiaContemporary-Through-Evolutions-ebook/dp/B06WGV26DT/ref=sr_1_2?s=digitaltext \&ie $=\mathrm{UTF} 8 \&$ qid $=1487803402 \&$ sr $=1-2 \&$ keywords=marketing + myopia

[34] Rakic, B., Rakic, M. (2017b): Sustainability-Oriented Mindset: Revolutionary Role of Sustainability Marketing as the Driver of Transformations for Sustainability, Digital Book, available at eBook retailers: Amazon.com - Kindle Store, etc. Kindle Edition, ASIN: B071X9H1XK, Retrieved from https://www.amazon.com/dp/B071X9H1XK/ref=sr_1_1?s=digitaltext\&ie=UTF8\&qid=1497462123\&sr=1-1\&keywords=SustainabilityOriented+Mindset $\% 3 \mathrm{~A}+$ Revolutionary+Role+of+Sustainability+Marketing+as+the+Driv er+of+Transformations+for+Sustainability

[35] Rao, P. (2002): Greening the supply chain: a new initiative in South East Asia. International Journal of Operations \& Production Management 22(6): 632-655.

[36] Sancha, C., Gimenez, C., Sierra, V. (2016): Achieving a socially responsible supply chain through assessment and collaboration. - Journal of Cleaner Production 112: 1934-1947.

[37] Searcy, C. (2014): Measuring Enterprise Sustainability. - Business Strategy and the Environment. doi: 10.1002/bse.1861.

[38] Smith, P., Easton, G. (1986): Network relationships: a longitudinal study. In: Third International IMP Research Seminar on International Marketing, Lyon: IRE.

[39] Seuring, S., Muller, M. (2008): From a literature review to a conceptual framework for sustainable supply chain management. - Journal of Cleaner Production 16(15): 16991710 .

[40] Tachizawa, E.M., Wong, C.J. (2015): The performance of green supply chain management governance mechanism: A supply network and complexity perspective. Journal of Supply Chain Management 51(3): 18-32. 
[41] Touboulic, A., Chicksand, D., Walker, H. (2014): Managing Imbalanced Supply Chain Relationships for Sustainability: A Power Perspective. Decision Sciences 45(4): 577-619.

[42] United Nations - UN. (2015). Transforming our world: the 2030 Agenda for Sustainable Development. https://sustainabledevelopment.un.org/content/documents/7891Transforming\%20Our\% 20World.pdf

[43] Wagner, T., Lutz, R.J., Weitz, B.A. (2009): Corporate hypocrisy: overcoming the threat of inconsistent corporate social responsibility perceptions. - Journal of Marketing 73(6): 77-91.

[44] Walker, H., Miemczyk, J., Johnsen, T., Spencer, R. (2012): Sustainable procurement: Past, present and future. - Journal of Purchasing \& Supply Management 18(4): 201-206.

[45] Zacharia, Z. G., Nix, N. W., Lusch, R. F. (2009): An analysis of supply chain collaborations and their effect on performance outcomes. - Journal of Business Logistics 30(2): 101-123.

[46] Zhao, X., Huo, B., Flynn, B.B, Heung, J.H.Y. (2008): The impact of power and relationship commitment on the integration between manufacturers and customers in a supply chain. - Journal of Operations Management 26(3): 368-388. 